\title{
PROCEDURAL JUSTICE AND DISTRIBUTIVE JUSTICE: EMPLOYEES ORGANIZATIONAL COMMITMENTS IN CREATIVE INDUSTRY
}

\author{
Asj'ari Fachrudy*, Utomo Sigit Prihanto, Suharyanto \\ Researchers, Indonesia \\ *E-mail: fachrudy@unipasby.ac.id
}

\begin{abstract}
The study aims to test and analyze organizational commitments of employees that are influenced by distributive and procedural justice in Surabaya. This study is included in the type of research survey used for explanation or confirmatory intent, or also called research for hypothesis testing i.e. to explain the influence of inter-variable or causal relationship between variables through Hypothesis testing. The sample of this study amounted to 100200 respondents consisting of creative industry employees in Surabaya. The sampling technique on this study was done by proportional method of random sampling. Data is obtained through the dissemination and re-collection of questionnaires and then analyzed by using SEM. The purpose of the research is to identify the organizational commitment of employees who are the distributive and procedural justice influenced in Surabaya obtained through research by making model designs. The relationship model of the researched variables results in a distributive and procedural justice that has an important link to organizational commitments. The results of this study also have significant for distributive and procedural justice so that the organizational commitment of employees in Surabaya is optimal.
\end{abstract}

\section{KEY WORDS}

Distributive justice, procedural justice, organizational commitments, organization, creative industry.

The judgment of justice is also heavily influenced by context or situation. In this case the most relevant context is the workplace or place of residence of the person concerned and the current atmosphere. In the previous section talked about systems and procedures, but there are other things that affect the assessment of distribution justice. Beyond that, various working conditions will ultimately affect the judgment because fairness and work satisfaction and life satisfaction are generally closely related.

Assessments of existing resources are usually directly related to the assessment of distributive justice. That is, people will consider the existing resource factors to assess the fairness of the divisions it receives. If the resources to be allocated are limited, people will be advised if they get a small division as well. Nevertheless, the person will compare with others and acceptance in the past. If the other person gets a big share even though the resources are limited, then he will feel unfairly treated when they get a small amount. It is clear that the actual relationship is not a distributive justice that affects the procedural justice, but the state of the resource is more instrumental.

Based on the description in the background it is known that, in general, the study aims to analyze how distributive and procedural justice influences the organizational commitments of employees.

The influence of justice assessment factors in the psychology of Justice Review is often limited to the subjective judgment of justice. Thus there may be inconsistency between justice in a state of reality (objective) with the judgment of justice (subjective). For example, by acclamation has been approved in distribution using the proportional principle and this principle has been implemented consistently. Objectively these conditions are judged fair. At the individual level it is possible that the emergence of unfair judgment relates to the distribution. This can happen because the reference of fairness for each individual is different. 
In the example above the likelihood of an assessment of injustice perhaps the appraiser chooses the principle of necessity or equalization. In addition, there may be certain interests in each appraiser that will affect the judgment. In more depth the judgment process itself can be examined based on the principles of cognitive psychology.

The following will be discussed some of the principles of cognitive psychology in question. First, in conducting assessments there is always cognitive processing as is generally the process of perception. The elements needed in this process include attention, encoding, and retrieval as the final result. Secondly, on this kind of process there are always limitations. The first limitation is the information itself. It is often encountered that to perform assessments it takes a lot of information. In fact, often the information is very limited in number and depth. In such circumstances this often happens shortcut assessment process. Consequently, the limited information is used as a valuation material and is regarded as an important source. Of course, there will be problems with the accuracy of judgment. Other limitations are often found on the ability to encoding. The ability of the human senses to do so is never perfect, while disruption in that process like the inclusion of other information is very likely to occur, therefore intentionally or not often the selection of the incoming information.

In addition to this in a process like this there is always an influence from the prior context to the assessment results. Thirdly, each individual has his own strategy in judging. One of the strategies that is often used is a heuristic thinking pattern. This strategy essentially aims to accelerate judgment, maximize existing information and make a good impression on the assessment by the environment. Fourth, the process and judgment results are always biased. However, that does not mean that the assessment cannot be held for further analysis.

In social sciences there is always a distinction of data between community values, individual opinions, and overt behavior. These three types of data should be viewed as objective data (as is) that stick to the object. This means that if a person's norms and behaviors are considered objective data, a person's judgment should also be considered objective at the person's level. Thus, the judgment of justice in this research will also be aligned with other data. Here the judgment of justice is considered to be in the text while other data will be regarded as the context.

\section{LITERATURE REVIEW}

Justice becomes an absolute condition in the relationship between people, in the life of society, nation, and state. The overwhelming demand for justice lately is actually normative demands. These demands arise at all levels of social life. Is this an indication that there is now no justice? If that is the case, why so far can we survive? According to the author's saving, the real problem is not whether there is justice but more because of the formulation of justice. Why? Fairness can be seen from various angles. At the moral level, fairness becomes a value that is highly esteemed by all walks of life. At the operational level in society the problem becomes very complex and difficult and often not easily accepted by various people. At the individual level, fairness is also difficult to formulate.

This principle is also difficult to implement. Criticisms at most come with regard to abandonment of potential and work productivity. A more clever, skilled or productive person should be rewarded higher, while this principle does not over consider it. Many opinions say that this principle is appropriately applied to the pattern of non-working relationships, such as family. In an atmosphere of work, this principle can be applied when the orientation is the harmony of the relationship of fellow workers. The third principle prioritizes needs as consideration for distribution. Here can be interpretation that the person will get a part according to his needs and in the work relationship more needs, the greater the wages received. There is evidence that the higher the part received will be the higher the productivity. Therefore, the need as a basis of distribution is assessed less motivating people to be more productive. 
In assessing procedural justice, there are two fundamental things that are influential. First is the personal interest (self interest). In line with the bias that occurs in the assessment process, personal interests also often lead to bias in judgment. So far in the social psychology has known self service and egoistic bias in the attribution process. The judgment of justice will also tend to be positive when in line with the interests of the parties or bring profit to it. The way to accomplish this is to influence or take a role in an existing procedure. Therefore, people who take control of the process or the content of the decision will generally give a more positive judgment than those who are not involved.

The second factor is the values of the group. Unlike the orientation of personal interests, many individuals are weighing together as assessment materials. That is, a procedure will be considered fair when the consideration of togetherness. The limit of togetherness is group. It is therefore referred to as a group value. The values of the group include respect for each other, the belief, and the unworthiness of one person or another group. Many things affect someone in assessing distributive justice. In this section will be examined by influential individual factors. Broadly, the individual factors in question can be categorized into psychological and non-psychological factors. Although both are distinguished, in reality the two are interconnected in influencing the judgment of justice. There is still an action that distinguishes men and women, including the distribution.

The principles of distributive justice vary greatly. However, there are three principles that are most commonly applied. The first principle is known as equity theory. Broadly, this principle contains two fundamental things. The part that a person receives should be comparable to a given donation, either in the form of energy, mind, money, or another.

In addition, the comparison of part that a person receives should also be seen with the part that other people receive. Therefore, the part received based on the contributions given must also be comparable to that of other people who are also based on the contributions of the person concerned. This proportional principle is ideal and not easy to implement. To apply it many conditions must be met. Among other things, a person's donation has to be measured.

The comparison of donations between one person and another in the company is also often difficult. Broom and scribe, for example, will be difficult to compare. Seeing this fact, a lot of criticism was told to him and the modification of theory was much sought. The second principle that can be used in distribution is equality or equality. When this principle is used, there will be a small variation of acceptance. There is a variation when there are types of work or parts in a single organization or group. The variation occurs between groups, not within each group. According to Allen and Meyer (1991, in Satta, 2000), the organizational commitment is a psychological attachment based on three-Component Model of Organizational Commitment; Affective, normative, and continuity commitment. Clearly the three shapes in question will be outlined consecutively below, as follows:

"Organizational commitments consist of three dimensions. First, employees with strong affective commitment (introduction and attachment to the organization) on the job continuously caused they want to do it (want to do). Secondly, employees who have a relationship with the organization that is based on continuity of commitment (aware of the costs associated with leaving the organization) are expected to remain in the organization because they need to do it (need to do). Third, employees with normative commitment (feelings for the assurance of rights to social pressures) feel that they should remain (ought to) with the organization".

Meyer, et al., (1993), emphasis the understanding of commitment by saying that separately employees have strong affective commitment because they feel like (want to) do it, have a strong normative commitment because they feel It should (ought to) do, and have a strong continuance commitment because they feel they need (need to)", (Meyer, et al., 1993, in Iverson and Buttigieg, 1998).

Organizational commitment is defined as the strength of an individual by identifying, engaging, and relating to the Organization. There are three main dimensions of the organizational commitment, namely: first, affective commitment; Commitment due to positive emotions about the Organization (affective commitment is a commitment demonstrated by 
positive feelings about the existence of the organization). Secondly, continuity commitment; Commitment to the organization because of the high perceived cost of leaving it (the continuance commitment is a commitment to the organization due to the high cost that will be received when leaving the organization). Third, normative commitment; Commitment because of an employee's internalization of organizational values and goals, and the associated sense of obligation (a normative commitment is a commitment due to the internalization process of an employee on the objectives and values, and relate to his feelings as an obligation)", (Aldag and Reschke, 1997).

The same sense is also expressed by Allen and Meyer (1990), that "the affective commitment as an emotional attachment through, identification with, and involvement in the organization. A continuation commitment is defined as a commitment based on the cost associated with the employee when leaving the organization, and normative commitment as the feeling of an employee in the form of its obligation to remain with the organization. According to Hackett et al., (1994) and Mathieu and Zajac, (1990) The commitment of continuance commitment is often interpreted as calculative commitment "(Meyer and Allen, 1990; Mathieu and Zajac, 1990; Hackett et al., 1994, in Iverson and Buttigieg, 1998).

An affective commitment is a commitment that employees have because of the values that the employee has, in line with the values that the organization has, where they work, and marked as the psychological emotions of employees to the organization. The continence commitment is the commitment that employees have because of the enormous consideration of something that has been invested (energy, mind, and time) when leaving the organization, and described as a necessity to Live in an organization. Normative commitment is a commitment that employees have because they feel obligated to serve their organization. Employee loyalty is expressed in a way that works on its organization, marked by trust because of the obligation to remain in the organization (Meyer and Allen, 1991, in Brown and Kristina, 2002).

The affective commitment points to the emotional attachment of an employee on, identifying with and involvement in the Organization and its objectives. Affective commitments result in employees having "wanting" to stay within the organization. A continuation commitment is a calculation and an exchange based on characteristics and pointing at costs associated with the choice of leaving the organization. The continuance commitment of generating feelings in their individual tends to have to be in relationship due to too much expense when it will leave the organization (such as retirement sacrifice, status, seniority), or they will get Limited work alternatives elsewhere. Lastly, normative commitments point to the desire of an employee to stay with an organization based on feelings in their individual who tend to ought against existing connections because that decision is the right mind to Done (Clugston et al., 2000).

\section{METHODS OF RESEARCH}

In this study used SEM analysis (structural equation modeling). According to Ferdinand (2002:6), Structural Equation Modeling (SEM) is a collection of statistical techniques that allow the testing of a series of relatively "complex" relationships. That complex relationship can be constructed between one or more dependent variables with one or more independent variables. Sampling techniques use proportional random sampling with a sample of 100 people.

Ferdinand (2002:33), a step of the SEM modeling can be performed as follows: 1. Development of theoretical models, 2. Development of chart paths, 3. Conversion of chart paths into equations, 4. Selection of input matrix and estimation model, 5. Assessing the problem Identification, 6. Evaluation Model, 7. Interpretation and modification of models.

\section{RESULTS AND DISCUSSION}

There is some assumption that testing is done in SEM, namely data normality test and Interference linearity. 
Table 1 - The Assumptions of SEM

\begin{tabular}{|ccc|c|c|c|c|}
\hline \multicolumn{2}{|c|}{ Relationship } & & Estimation & P & Alpha & Label \\
\hline Y1 & $<---$ & X1 & 0.421 & 0.002 & 0.05 & Significant \\
Y1 & --- & X2 & 0.236 & 0.027 & 0.05 & Significant \\
X1.1 & --- & X1 & 0.432 & 0.000 & 0.05 & Significant \\
X1.2 & --- & X1 & 0.511 & 0.000 & 0.05 & Significant \\
X2.1 & $<--$ & Y1 & 0.252 & 0.000 & 0.05 & Significant \\
X2.2 & $<--$ & Y1 & 0.643 & 0.000 & 0.05 & Significant \\
X2.3 & $<---$ & Y1 & 0.053 & 0.000 & 0.05 & Significant \\
X2.4 & $<---$ & Y1 & 0.631 & 0.000 & 0.05 & Significant \\
X2.5 & $<---$ & Y1 & 0.342 & 0.000 & 0.05 & Significant \\
Y1.1 & $<---$ & Y2 & 0.156 & 0.000 & 0.05 & Significant \\
Y1.2 & $<---$ & Y2 & 0.631 & 0.000 & 0.05 & Significant \\
Y1.3 & $<---$ & Y2 & 0.527 & 0.000 & 0.05 & Significant \\
\hline
\end{tabular}

Table 2 - Results of Testing the Assumptions of Linearity

\begin{tabular}{|c|c|c|c|}
\hline Exogenous Variable & Endogenous Variable & Test Result $(\alpha=0,05)$ & Decision \\
\hline Procedural justice $\left(X_{1}\right)$ & Organizational Commitments $\left(Y_{1}\right)$ & Significant linear models & Linear \\
\hline Distributive justice $\left(X_{2}\right)$ & Organizational Commitments $\left(Y_{1}\right)$ & Significant linear models & Linear \\
\hline
\end{tabular}

A hypothesis test is performed with a $T$ test (T-Test) on each direct influence. Complete analysis of the results contained in SEM analysis results.

Hypothesis 1: Procedural justice $(\mathrm{X} 1)$ has significant effect on organizational commitment $(\mathrm{Y} 1)$. The result of the analysis of the procedural Justice variable (X1) has significant effect on the organizational commitment ( $\mathrm{Y} 1$ ), acquired line coefficient 0421 and P-value 0.002. Empirical evidence to accept the hypothesis that procedural justice (X1) has significant effect on organizational commitment (Y1). The path coefficient is marked positively (0421), meaning the relationship of these two variables is positive; it means the better the procedural justice, the higher the organizational commitments.

Hypothesis 2: Distributive justice (X2) significantly affects organizational commitment (Y1). The result of SEM analysis of the distributive Justice variable (X1) has significant effect on the organizational commitment (Y1), obtained the line coefficient 0236 and $\mathrm{P}$-value 0.027 . Empirical evidence to accept the hypothesis that distributive justice (X2) has significant effect on organizational commitment (Y1). The path coefficient is negatively marked. Meaning the relationship of these two variables is positive (0236), it means the better the distributive justice, the higher the organizational commitments.

\section{CONCLUSION AND SUGGESTIONS}

Based on the analysis results that refers to research objectives, hypotheses and analytical models, it can be concluded as follows:

- Procedural justice has significant and positive effect on the organizational commitment of employees of 1 creative industry sub-sector in Surabaya;

- The distributive justice has significant and positive effect on the organizational commitment of employees of 1 creative industry sub-sector in Surabaya.

Based on the research results and conclusion that has been taken, the suggestions that can be submitted by the authors to the relevant parties are as follows:

Procedural justice. Based on the principle of justice, when employees perceive an injustice, then they can predict to take one of six choices, namely: 1) change their input, 2) change their output, 3) distort the perception of self, 4) distort the perception of others, 5) Choose different references, 6) quit the Job (Robbins, 2006). Procedural justice is a justice that pays attention to mechanisms that support employee empowerment and provide support to employees. Procedural justice is referring to the regulatory justice and procedures whereby the awards are distributed (Alexander and Ruderman, 1987 in Supardi, 2008). Referring to the opinions of Cropanzano et al., in Beugre (1998) that a fair organization one of which is characterized by a procedure that guarantees it as a statement, process, warning, and so on. Procedural justice involves the formal characteristics of a system, and one of the 
obvious indicators of procedural justice is the presence of several mechanisms that govern clearly for employees to say about something that is happening in its work. Magner et al., in Beugre (1998) argues that managers or leaders should avoid the use of arbitrary and arbitrarily procedures in allocating existing work resources. In order for the organization to do so, the manager/leader must develop the rules or procedures relating to the work clearly and in which there are communication mechanisms from the ground up (proposed). If this is the case, it is likely that this will impact the employee's commitment to the company.

Distributive justice. The purpose of distribution here is the welfare covering the physical, psychological, economic, and social aspects, so that the distributed ones are usually related to resources, rewards or profits. Distribution based on needs has the concept that the employee acceptance part is influenced by his needs relating to the work. The more needs for the employees, the acceptance of the work becomes increasingly high (Deutsch in Beugre, 1998). From the theoretical study above it can be concluded that distributive justice is a perception of values received by employees based on the outcome/acceptance of a circumstance or item capable of affecting the welfare of the employees. Distributive justice can essentially be achieved when the outcome/acceptance and input between two persons/two employees is comparable. If from a comparison of the accepted proportions is comparable or greater, then it is likely that it is fair, and this has an impact on the outcome of their work. But when from the comparison of the proportion received is smaller than the other, it is likely that it is said to be unfair so that it will affect the outcome of their work (Supardi, 2008).

Organizational commitments. Theoretically the discussion on the concept of general and diverse organizational commitments, such as Satta (2002) said that thousands of literature in articles have been published about the concept of commitment, since its introduction Organizational behavioral studies in the years 1950-an. Therefore, before specifically articulating them, below presented some important thoughts on the organizational commitments. There are three different approaches to interpreting commitment. First, the exchange (side bets) approach looks at the commitment as a result of the contribution of transactions between the organization and its members. Secondly, the psychological approach defines a commitment as an attitude or orientation to an organization that relates to an organization's identification (Varona, 1996). Thirdly, the attribution approach defines commitment as individual attachment to the behavior of actions and occurs when individual attributes and commitment attributes converge in behavior based on their own willpower, Clear, and Irrevocable (Reichers, 1985 in Varona, 1996).

\section{REFERENCES}

1. Allen, N.J., and Meyer J.P. 1990. The measurement and antecedents of affective, continuance, and normative commitment to the organization. Journal of Occupational Psychology, vol. 63, pp. 1-18.

2. Allen, N.J., and Meyer J.P. 1991. Affective, continuance, and normative commitment to the organizational: an examination of construct validity. Journal of Vocational Behavior, vol. 43. pp. 252-276.

3. Andersson, L.M., and Bateman T.S. 1997. Cynicism in the workplace: some causes and effects. Journal of Organizational Behavior, vol. 18, no. 5, pp. 449.

4. Becker, H.S. 1960. Notes on the concept of commitment. American Journal of Sociology, vol. 66, pp. 32-42.

5. Brown III, U.J., and Gaylor K.P. 2006. Organizational commitment in higher education. Paper: Organizational Behaviour/Organizational Theory. Jackson State University. email: kpgaylor@jsums.edu.

6. Buchanan, B. 1974. Building organizational commitment: the socialization of managers in work organizations. Administrative Science Quarterly. vol. 19, pp. 533-546.

7. Cappelli, P., and Rogovsky, N. 2007. Employee involvement and organizational citizenship: implications for labor law reform and lean production. Industrial and Labor Relations Review, vol. 51, no. 4, pp. 633-653. 
8. Carmeli, A.F. 2004. Work commitment, job satisfaction, and job performance: an empirical investigation. International Journal of Organizational Theory and Behavior, vol. 7(3), pp. 289-309.

9. Clugston, M., Howell J.P., and Doreman P.W. 2000. Organizational, commitment across cultural, dimensions. Journal of Management. vol. 26. no. 1. pp. 1-30. JAI PRESS Inc. Stamford.

10. Dessler, G. 1997. Manajemen personalia. Edisi Ketiga (Terjemahan dari Agus Dharma). Jakarta: Penerbit Erlangga.

11. Ferdinand, A. 2002. Structural Equation Modeling Dalam Penelitian Manajemen: Aplikasi Model-Model Rumit Dalam Penelitian Untuk Tesis Magister dan Disertasi Doktor. Semarang: Penerbit Fakultas Ekonomi Universitas Diponegoro.

12. Fisher, C.D. 1986. Organizational socialization, in Ferris, G.R. and Rowland, K.M. (Eds). An integrative Review. Research in Personnel and Human Resources Management, vol. 4, pp.

13. Gomez-Meija, L.R., and Balkin D.B. 2002. Compensation, organizationa; strategy, and firm performance. Cincinnati: South-Western Publishing Co.

14. Greenbneg, J., and Baron R.A. 1997. Organizational behavior. 6 ${ }^{\text {rd }}$. Prentice Hall International Editions.

15. Hasibuan, S.P., and Malayu 2002. Manajemen sumber daya manusia. Edisi Revisi. Cetakan Kelima. Jakarta: Penerbit PT. Bumi Aksara.

16. Henkin, A.B., and Marchiory D.M. 2003. Empowerment and organizational commitmentt of chiropractic faculty. Journal of Manipulative and Physiological Therapeutics, vol. 26(5), pp. 2-6.

17. Koh, H.C., and Boo H.Y.E.L. (2004). Organizational ethics and employee satisfaction and commitment. Management Decision, vol. 42, no. 5, pp. 677-693.

18. Lapierre, H. 2001. Understanding the links between work commitment constructs. Journal of Vocational Behaviour. pp. 350-413.

19. Luthans, F. 1992. Organizational Behavior. Eight Edition. New York: Mc Grawhill.

20. Mangkunegara, A.P. 2001. Manajemen Sumber Daya Manusia Perusahaan. Bandung: Remaja Rosdakarya.

21. Mayer, R.C., and Schoorman, F.D. 2007. Differentiating antecendents of organizational commitment: a test of march and simond's model. Journal of Organizational Behavior, vol. 19, pp.15-28.

22. Meyer, J.P., Irving, P.G., and Allen N.J. 1993. Person $x$ environment interaction in the development of organizational commitment. Presented at the annual meeting of the American Psychological Association. Toronto, Ontario.

23. Morrison, E.W. 1994. Role definitions and organizational citizenship behavior: the importance of the employee's perspective. Academy of Management Journal, vol. 37. pp. 1543-1567.

24. Mowday, R.T., Steers R.W., and Porter L.W. 1979. The measurement of organizational commitment. Journal of Vocational Behavior, vol. 14, pp. 224-47.

25. Nasir, Moh. 1999. Metode Penelitian. Cetakan Keempat, Jakarta: Penerbit Ghalia Indonesia.

26. Parker, M. 2000. Industrial relations myth and shopfloor reality: the team concept: in the auto industry, in Lichtenstein, N., and Howell, J.H. (Eds), Industrial Democracy in American. Cambridge: Cambridge University Press.

27. Radiq, M. 1998. Manajemen Sumber Daya Manusia. Edisi Ketiga. Jakarta: Ghalia Indonesia.

28. Robbins, S.P. 2003. Perilaku organisasi. Buku 1. Edisi Indonesia. Jakarta: Penerbit PT. INDEKS Kelompok GRAMEDIA.

29. Steers, R.M. 1977. Antecendents and outcomes of organizational commitment. Administrative Science Quarterly, vol. 22: pp. 46-56.

30. Sugiyono. 2002 . Metode penelitian bisnis. Bandung: Penerbit CV. Alfabet.

31. Wexley, K.N, and Yukl G.A. 2003. Perilaku organisasi dan psikologi personalia. Cetakan Kedua. Jakarta. Penerbit Rineka Cipta. 
32. Yoon, M.H., and Suh J. 2003. Organizational citizenship behaviors and service quality as external effectiveness of contact employees. Journal of Business Research. vol. 56. pp. 597-611. Elsevier Science Inc.

33. Yukl, A.G. 2002. Leadership in organizational. Fifth Edition. New Jersey: Prentice Hall. Upper Saddle River, 07458.

34. Niehoff, B. P \& Moorman, R. H. 1993. Justice As A Mediator Of The Relationship Between Methods of Monitoring And Organizational Citizenship Behavior. Academy of Management Journal. 36 (3): 327-556.

35. Robbins P.S., 2006. Prinsip-Prinsip Perilaku Organisasi. Penerbit PT Indeks: Jakarta.

36. Beugre, Constan D., 1998. Managing Fairness in Organizations. London: Quorum Books, Westport, Connecticut.

37. Supardi, 2008. Pengaruh Budaya Organisasi terhadap Keadilan Distributif dan Keadilan Prosedural serta Produktivitas Kerja Pegawai Hotel Berbintang di Daerah Istimewa Yogyakarta. Optimal, Vol. 6, No. 1. 